\title{
Archaeological Pedestrian Survey and NRHP Eligibility Testing of 41WB414 for the Killam Lake Wetlands Area on Chacon Creek, Webb County, Texas
}

Leonard Kemp

Center for Archeological Research, University of Texas at San Antonio

Follow this and additional works at: https://scholarworks.sfasu.edu/ita

Part of the American Material Culture Commons, Archaeological Anthropology Commons, Environmental Studies Commons, Other American Studies Commons, Other Arts and Humanities Commons, Other History of Art, Architecture, and Archaeology Commons, and the United States History Commons

Tell us how this article helped you.

This Article is brought to you for free and open access by the Center for Regional Heritage Research at SFA ScholarWorks. It has been accepted for inclusion in Index of Texas Archaeology: Open Access Gray Literature from the Lone Star State by an authorized editor of SFA ScholarWorks. For more information, please contact cdsscholarworks@sfasu.edu. 


\section{Archaeological Pedestrian Survey and NRHP Eligibility Testing of 41WB414 for the Killam Lake Wetlands Area on Chacon Creek, Webb County, Texas \\ Creative Commons License \\ (c) (1) (9)}

This work is licensed under a Creative Commons Attribution-NonCommercial 4.0 International License 


\section{Archaeological Pedestrian Survey and NRHP Eligibility Testing of $41 \mathrm{WB} 414$ for the Rillam Lake Wetlands Area on Chacon Creek, Webb County, Texas}

Leonard Kemp

Texas Antiquities Permit No. 4807

Prepared for:

City of Laredo

315 9th Street, Suite 1

Laredo, Texas 78215-1525

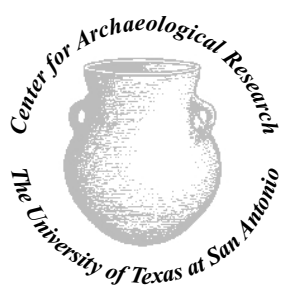

(C) 2008
Prepared by:

Center for Archaeological Research

The University of Texas at San Antonio Archaeological Report, No. 389 


\section{Archaeological Pedestrian Survey and the NRHP Eligibility Testing of $41 \mathrm{WB} 414$ for the Killam Lake Wetlands Area on Chacon Creek, Webb County, Texas}

by

Leonard Kemp

Texas Antiquities Committee Permit No. 4807

Principal Investigator

Antonia L. Figueroa

Prepared for:

City of Laredo

315 9th Street, Suite 1

Laredo, Texas 78215-1525

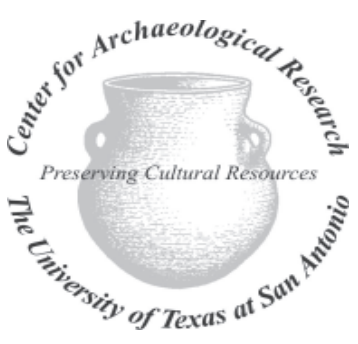

(C) 2008
Prepared by:

Center for Archaeological Research The University of Texas at San Antonio Archaeological Report No. 389 



\begin{abstract}
:
In February of 2008, the Center for Archaeological Research (CAR) at The University of Texas at San Antonio (UTSA) conducted a 100 percent pedestrian survey of the Killam Lake Wetland Area located along Chacon Creek in Laredo, Webb County, Texas. Archaeological sites 41WB413 and 41WB414 were revisited as part of the archaeological investigations and eligibility testing was conducted on 41WB414. The archaeological work was completed for the City of Laredo Solid Waste Services Department, who planned to remove construction and industrial debris from the waterway, as part of a wetlands restoration project. Because the removal process has the potential to impact the Chacon Creek waterway, the project falls under the jurisdiction of the U.S. Army Corps of Engineers (USACE). As such, the undertaking is subject to archaeological investigations as stated in Section 106 of the National Historic Preservation Act (NHPA). The archaeological survey and eligibility testing were conducted under Texas Antiquities Permit No. 4807 with Leonard Kemp serving as the Project Archaeologist and Antonia L. Figueroa serving as the Principal Investigator.
\end{abstract}

CAR excavated 60 shovel tests and three 1-x-1 m test units within the Area of Potential Effect (APE). No new sites were documented during the pedestrian survey. No evidence of cultural features or intact cultural horizons was noted upon inspection of $41 \mathrm{WB} 413$ and no further work on that site is recommended. CAR has proposed that the boundary of $41 \mathrm{WB} 414$ be extended to the west. Based on the findings from test unit excavations at 41WB414, CAR concurs with the previous assessment that 41WB414 is not eligible for inclusion to the National Register of Historic Places.

The planned improvements to the APE can proceed and no further archaeological work is recommended on this property. CAR recommends that the proposed wetland project proceed as planned.

Artifacts collected and records generated during this project were prepared for curation according to Texas Historical Commission guidelines and are permanently curated at the Center for Archaeological Research at the University of Texas at San Antonio. 


\section{Table of Contents:}

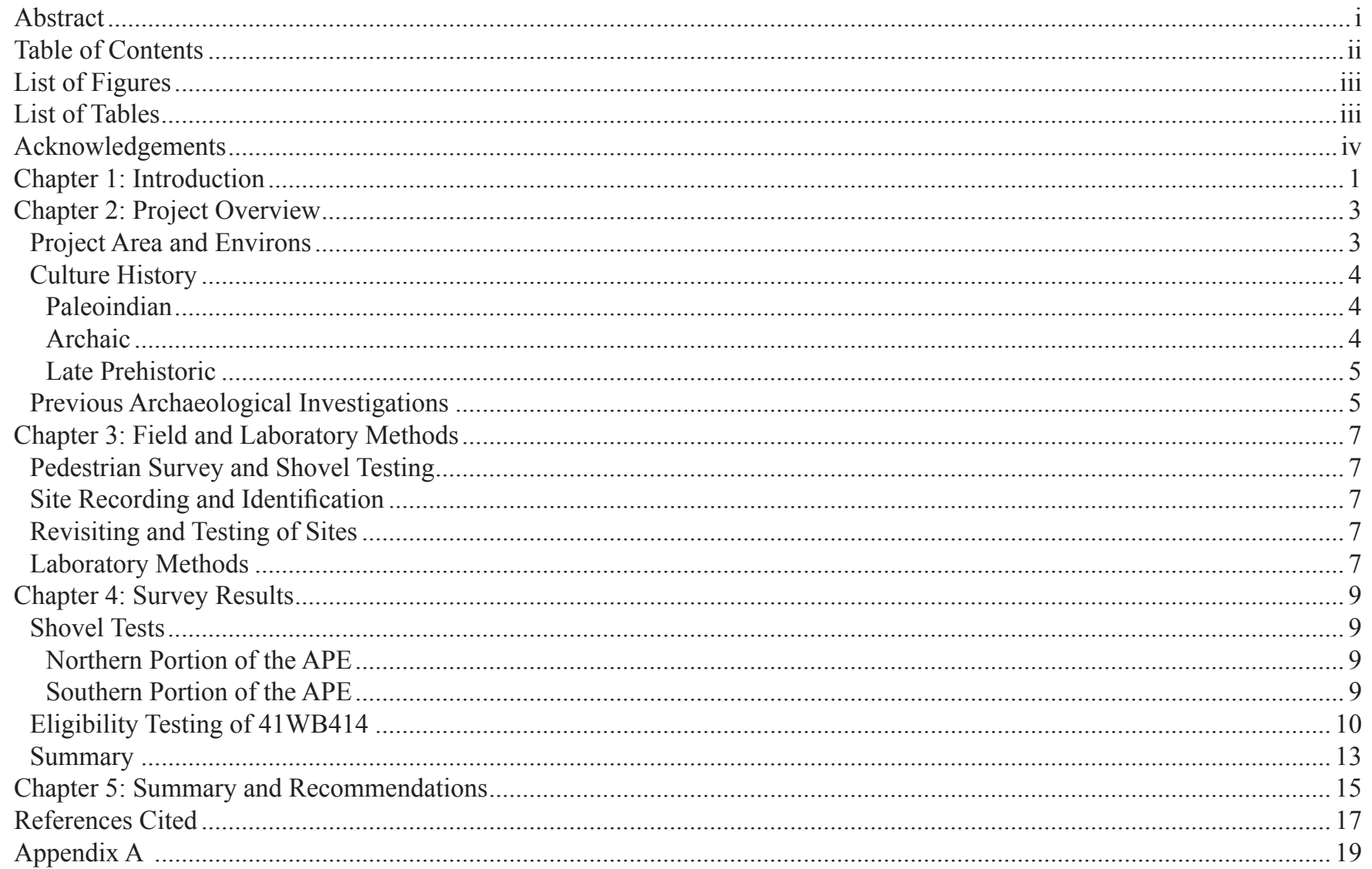




\section{List of Figures:}

Figure 2-1. The location of the project area on the Laredo East 7.5 Minute Series U.S.G.S. quadrangle maps........................ 3

Figure 2-2. Photograph depicting the project area showing the riparian vegetation of Chacon Creek..................................... 4

Figure 4-1. Map showing distribution and results of shovel testing.............................................................................

Figure 4-2. Photograph of "southern portion" of project area showing dense grass cover. ................................................... 10

Figure 4-3. Photograph of 41WB413 showing damage to site from erosion. ................................................................. 10

Figure 4-4. Map showing testing and surface artifacts on 41WB414 with proposed boundary extension. .............................. 11

Figure 4-5. Profiles and debitage total per level (in red) of the 41WB414 test units. ......................................................... 12

\section{List of Tables:}

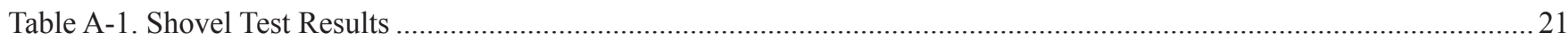

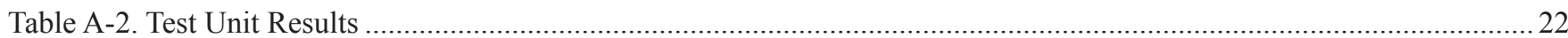




\section{Acknowledgements:}

Several individuals aided in the successful completion of this project. The Center for Archaeological Research would like to thank Stephen R.Geiss, Landfill Superintendent with the City of Laredo Solid Waste Services Department, for coordination of the project. We, also thank Adrian Gause, CFM., GIS Analyst, and Coordinator for the City of Laredo's Environmental Services Department for graciously providing maps and GIS data that facilitated the planning for the project. Finally, we thank Barbara Castille of S \& B Infrastructure, Ltd. for keeping the lines of communication open between all involved parties. The survey was completed by a field crew that included Cyndi Dickey, Jason Perez and Nathan DiVito. Dr. Raymond Mauldin and Dr. Steve Tomka provided comments on early drafts of the report. Leonard Kemp served as the Project Archaeologist with Antonia Figueroa serving as the Principal Investigator. Bruce Moses served as the technical editor. 


\section{Chapter 1: Introduction}

The City of Laredo Solid Waste Services Department will be conducting remediation of the Killam Lake Wetland Area immediately east of the city limits of Laredo in Webb County, Texas. These efforts will include the removal of modern construction and industrial debris deposited along this segment of Chacon Creek. The removal process has the potential to impact Chacon Creek waterway and therefore falls under the jurisdiction of the U.S. Army Corps of Engineers (USACE). As such, the undertaking is subject to archaeological investigations as stated in Section 106 of the National Historic Preservation Act (NHPA). One outcome of the NHPA was the creation of the National Register of Historic Places (NRHP) and the Advisory Council of Historic Preservation. Section 106 of the NHPA stipulates that the Advisory Council must be given "a reasonable opportunity to comment" regarding the effect of any undertakings that could impact properties that may be eligible for inclusion in the National Register. The archaeological survey and eligibility testing were conducted under Texas Antiquities Permit No. 4807 with Leonard Kemp serving as the Project Archaeologist and Antonia L. Figueroa serving as the Principal Investigator.

The City of Laredo Solid Waste Services Department, through the City Manager's Office, contracted with the Center for Archaeological Research (CAR) at the University of Texas at San Antonio (UTSA) to conduct the required investigations. CAR conducted a 100 percent pedestrian survey of the Killam Lake Wetlands Area. In addition, CAR investigated two previously identified sites (41WB413 and 41WB414) to determine if any deposits were present that would warrant the nomination of these sites to the NRHP and/or their formal listing as State Archeological Landmarks (SAL).

The Killam Lake Wetlands Area, also the Area of Potential Effect (APE), encompasses approximately 18 acres (ca. $72,850 \mathrm{~m}^{2}$ ). Of the total acreage, Chacon Creek channel occupies four acres, leaving 14 acres (ca. 56,250 $\mathrm{m}^{2}$ ) that could be surveyed. The survey of the Killam Lake Wetland Area included the excavation of 60 shovel tests. In the process of conducting the survey no new sites were identified. The boundary of site $41 \mathrm{WB} 414$ was extended based on positive shovel tests. In addition to the shovel testing, three test units were excavated within and adjacent to 41WB414. Site 41WB413 was revisited as part of the archaeological investigations and further work on the site is not recommended. Given that the nature of the deposits at $41 \mathrm{WB} 413$ are not eligible for listing in the NRHP and severe erosion has impacted 41WB413, CAR recommends that the cleanup of the Killam Lake Wetlands proceed as planned.

Theremainder of this document summarizes the archaeological fieldwork and provides recommendations regarding the management of cultural resources. This report is organized into five chapters. Chapter 2 provides a brief overview of the project area and summarizes the archaeological knowledge about the region. Chapter 3 discusses the fieldwork and laboratory methodology used during the project. The results of the archaeological survey are presented in Chapter 4. Chapter 5 summarizes the work and provides recommendations for the Killam Lake Wetland Area project. 



\section{Chapter 2: Project Overview}

This chapter presents a brief description of the Killam Lake Wetlands project and characterizes the project area, environs and the culture history of South Texas. The chapter concludes with a summary of previous archaeological work conducted in the vicinity of the project area.

\section{Project Area and Environs}

The project area lies immediately east of the City of Laredo in Webb County as shown on the Laredo East 7.5' series USGS quadrangle maps. Figure 2-1 shows the location of the Area of Potential Effect (APE) and the location of Webb County in south Texas. Located at an elevation of 380-400 $\mathrm{ft}$ amsl (155-121 m), the Killam Lake Wetlands is part of the Chacon Creek drainage. The Chacon drainage is a major tributary of the Rio Grande/Rio Bravo River with the project area approximately $3.7 \mathrm{~km}$ from the confluence of the two systems. Figure 2-2 shows the Chacon Creek and the riparian environment along its course. Present land use adjacent to the project area is industrial, commercial and residential.

The project area lies within the South Texas Brush Country physiographic province of Texas and the boundaries of the Chihuahuan, Balconian, and Tamaulipian biotic provinces (Blair 1950). The modern vegetation is dominated by a mixture of creosote bush (Larrea tridentata), mesquite (Prosopis sp), prickly pear (Opuntia sp.) and other cacti species. Modern grasses found today include Bermuda grass (Cyndon dactylon), Johnsongrass (Sorghum halepense), and buffalo grass (Cenchrus ciliaris). In riparian environments,

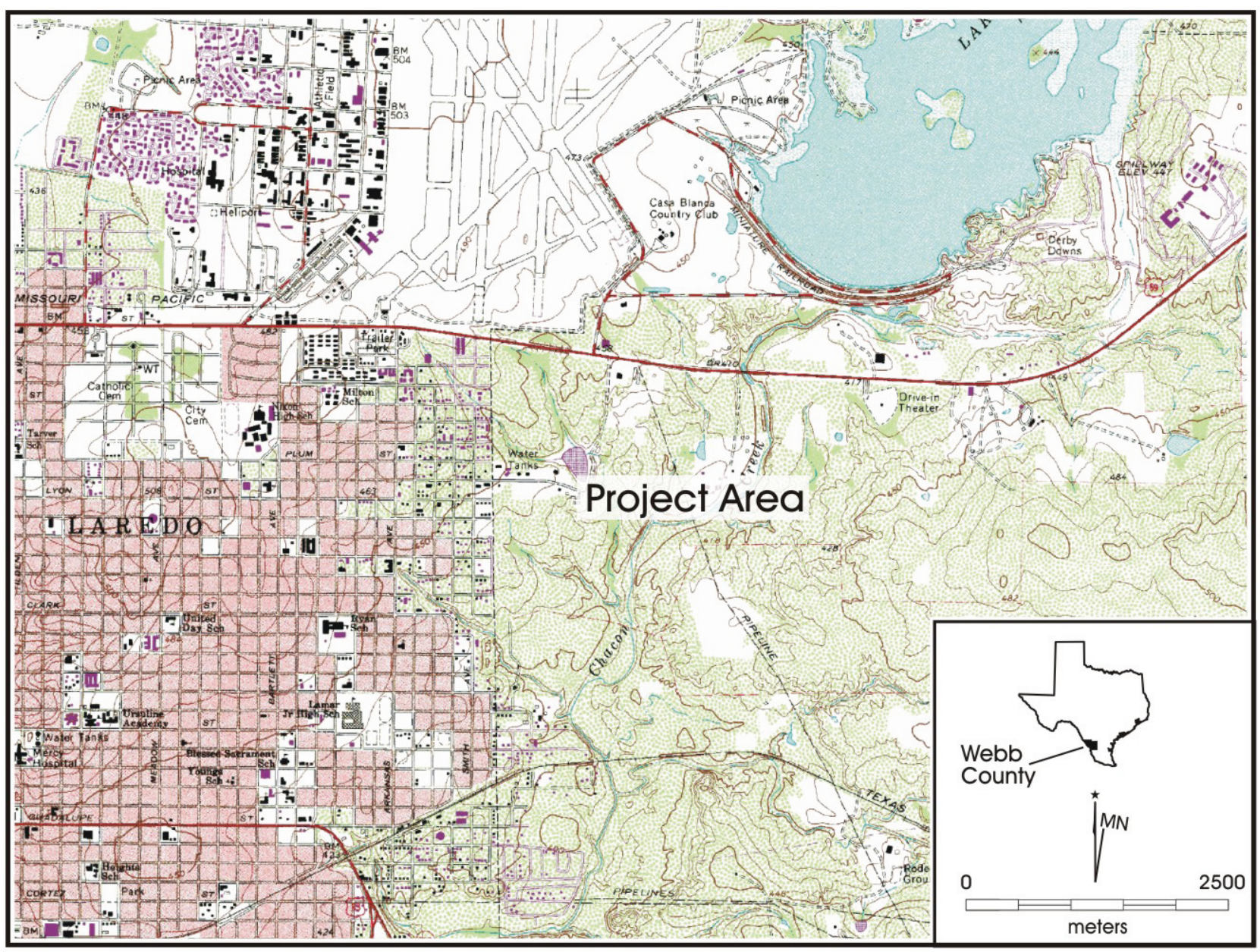

Figure 2-1. The location of the project area on the Laredo East 7.5 Minute Series U.S.G.S. quadrangle maps. 


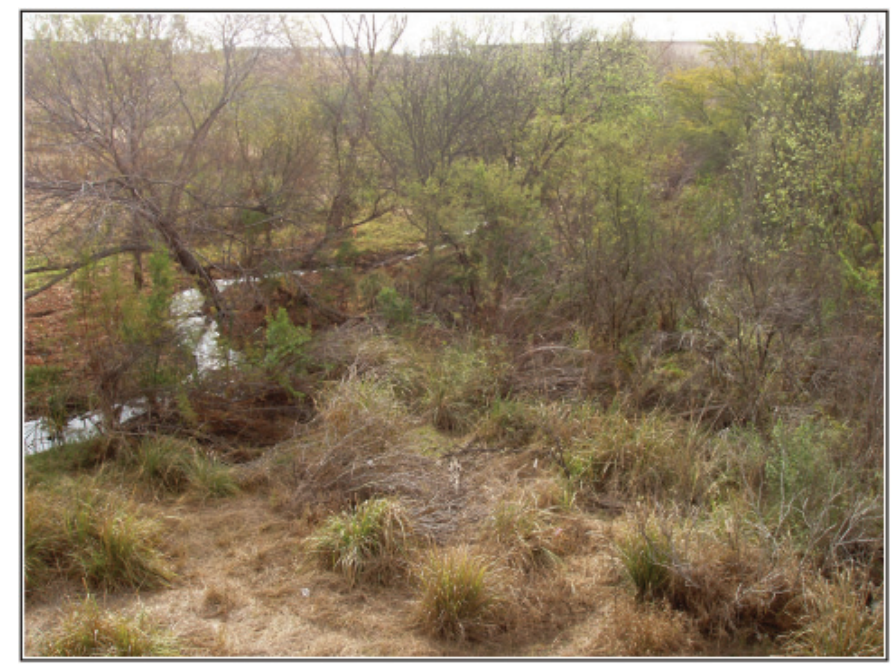

Figure 2-2. Photograph depicting the project area showing the riparian vegetation of Chacon Creek.

live oak (Quericus sp.), cottonwood (Populus fremontii), sugar hackberry (Ceitis laevigata), and sycamore (Platanus occidentalis) can be found. Blair (1950) lists 61 animal species native to the region including white-tailed deer (Odocoileus virginianus), cottontail (Sylivilagus floridanus) and jackrabbits (Lepus californicus). Bison (Bison bison), pronghorn(Antilocapraamericana), bear(Ursusamericanus), wolf (Canis lupus) and jaguar (Felis onca) were all once found in the region, although no longer. Modern species introductions include the armadillo (Dasypus novemcinctus) and javelina (Pecari tajacu).

Soils in the project area are classified as the Copita-Verick soil series (Sanders and Gabriel 1985). These soils include the dominant Verick and Copita series on the uplands and the Tela series within these drainages. Verick soils are described as shallow, fine sandy loams that are suitable for wildlife habitats (Sanders and Gabriel 1985:11). The Copita series are moderately deep sandy loams and sandy clay loams (Sanders and Gabriel 1985:11). The Tela series is a deep, well drained loamy soil (Sanders and Gabriel 1985:85).

The climate of Laredo is subtropical and has an average annual rainfall of 19.8 inches with an average annual temperature of $73^{\circ} \mathrm{F}$ (Sanders and Gabriel 1985). Summer months are hot with an average of $85^{\circ} \mathrm{F}$ and winters are warm to cool with an average temperature of $58^{\circ} \mathrm{F}$. Rainfall is most abundant in spring and fall with approximately 70 percent of the annual rainfall occurring between April through September (Sanders and Gabriel 1985). The growing season averages 300 days per year (Sanders and Gabriel 1985).

\section{Culture History}

Webb County has over 600 recorded archaeological sites, though there is a lack of well-documented archaeological excavations in the region (Quigg et al. 2000; THC 2008). The following discussion of this region is based primarily on the chronologies developed by Hester (1995), Hall et al. (1986), and Tomka et al. (1997). The cultural chronology of South Texas is supplemented with reference made to trends found in Central Texas (Collins 1995). This section outlines a brief cultural chronology of the region to provide context for the archaeological work that was conducted by CAR.

\section{Paleoindian}

The Paleoindian period (11,500-8800 BP) is characterized by projectile points that include lanceolate-shaped, fluted forms such as Clovis, Plainview, and Folsom. (Collins 1995). The period begins at the close of the Pleistocene and terminates with the Early Holocene climate shift from a wetter cooler to a dryer and warmer period. In Webb County, a small number of Clovis and Folsom points, all isolated surface finds, have been found indicating a Paleoindian presence, though no Paleoindian sites have been documented in Webb County to date.

\section{Archaic}

The Archaic period in Central Texas (8800-1200 BP) is marked by intensification in hunting and gathering of local resources and by a broader array of material culture (Collins 1995). This general pattern is typically assumed for South Texas. There is a lack of extensive excavations, and preservation of faunal and plant is poor at sites (Quigg 2002:27). The Archaic period of South Texas is subdivided into Early, Middle and Late Archaic sub-periods (Hester 1995). Reconstructions of Early Archaic adaptations in South Texas are based on the presence of an early corner-notched dart point forms dating from ca. 6000 to 3500 B.C. The subsequent early basal-notched dart points dates from 3600 to 3000 B.C. (Hester 1995:436). The Middle Archaic dates from 2500 B.C. to 400 B.C. Diagnostic artifacts associated with this period include an unstemmed dart point, the Tortugas, the Abasolo, and small unifacial and bifacial tools (Hester 1995). An exception to the lack of welldocumented Archaic period sites is the Lino site (41WB437). The Lino site is unique for South Texas archaeology in that it is a well-stratified site that contained an abundant lithic assemblage, as well as evidence of subsistence practices (see Quigg et al. 2000). The Desmuke, Matamoros, and Catan points are diagnostic forms of the Late Archaic period, as well as large (15-20 cm long), thin, triangular bifaces, made of non-local chert typically found in the Rio Grande Plains area (Hester 1995:442). 


\section{Late Prehistoric}

The beginning of the Late Prehistoric period (1150/ 1200-350 BP) is marked by the appearance of arrow points, indicative of bow and arrow technology, and pottery (Hester 1995). Arrow points unique to South Texas include the Matamoros, Cameron, Catan, Starr and Maud (Quigg 2002). Leon Plain, bone-tempered ceramics are a dominant characteristic of the Late Prehistoric. Ceramics of this type are rarely found south of the Nueces River (Quigg et al. 2002:36). The Boiler site (41WB557) investigated by Quigg et al. (2002) is a stratified site containing components that date from the Middle Archaic through the Late Prehistoric periods. The Scallorn, Perdiz and Toyah projectile point forms are also found in South Texas (Turner and Hester 1993).

\section{Previous Archaeological Investigations}

Several archaeological projects have been conducted in the immediate vicinity of the project area and adjacent to Chacon Creek (THC 2008). The Chacon Creek drainage consists of two terraces and a modern floodplain. Previous geoarchaeological (Maslyk et al. 1997) work suggests that Terrace $1\left(\mathrm{~T}_{1}\right)$ of Chacon Creek has potential for containing intact early to middle Holocene alluvial deposits in sections not severely eroded (Maslyk et al. 1997). Terrace $2\left(T_{2}\right)$ is reported as deflated, deeply gullied and has poor potential for intact archaeological deposits (Kibler 1996; Maslyk et al. 1997). The findings from five archaeological sites within a two kilometer radius of the project area are summarized in this section.

41WB9 is a large prehistoric campsite with a historic component (Maslyk et al. 1997). It is situated on $T_{1}$ and $T_{2}$ of Chacon Creek and located approximately $1.2 \mathrm{~km}$ north of the project area. The site, based on diagnostics and radiocarbon dating, represents Middle Archaic through Late Prehistoric periods. The historic component may date to the Spanish Colonial period based upon the presence of at least one adobe lime kiln (Maslyk et al. 1997). Both components are potentially eligible for listing in the NRHP (Maslyk et al. 1997).

41WB222 is described as a large Late Prehistoric site based on temporal diagnostics (Clark 1992). It is located on $T_{1}$ and $T_{2}$ of Chacon Creek. Clark's (1992) investigation, while limited to the right-of-way (ROW), suggests that archaeological deposits extended beyond the ROW on the surface and in the first levels (Clark 1992). Unfortunately, the majority of the known site was impacted by mining, construction, plowing and erosion (Clark 1992). The site is not eligible for listing in the NRHP or for designation as a SAL.
41WB223 is a Late Archaic through Late Prehistoric site and is located on $T_{1}$ and $T_{2}$ of Chacon Creek (Clark 1992). At the time of investigation, 41WB223 was not impacted by plowing, but was extensively eroded. Since that time the area surrounding 41WB223 has been developed. Cultural material was found on the surface and in Level $1(0-10 \mathrm{cmbs})$. The site is not eligible for listing in the NRHP or for designation as a SAL.

Sites 41WB413 and 41WB414 were discovered in conjunction with the planned extension of a sewer line (Kibler 1996:1-2). The sites were thought to be potentially eligible for inclusion in the NHRP and were tested.

41WB413 was recorded as an open campsite situated on $\mathrm{T}_{1}$ of Chacon Creek (Kibler 1996; Maslyk et al. 1997). Previous investigations recovered diagnostic from the Middle Archaic through the Late Prehistoric periods. 41WB413 was investigated with three units that focused on a feature eroding from a cut bank of Chacon Creek (Maslyk et al. 1997 25-29). A radiocarbon sample, submitted to Beta Analytic, was found to be inconclusive (Maslyk et al. 1997 28). All temporal diagnostic associated with 41WB413 were found on the surface. Maslyk et al. (1997) reported that the northern portion of the site was heavily eroded, although the southern portion may contain intact deposits. Maslyk et al. (1997) recommended that the site is not eligible for listing in the NRHP or for designation as a SAL.

41WB414 was also recorded as an open campsite (Kibler 1996; Maslyk et al. 1997). It is situated on $\mathrm{T}_{1}$ of Chacon Creek (Kibler 1996; Maslyk et al. 1997). Diagnostic artifacts found on the surface suggest a relatively long occupation spanning the Middle Archaic through the Late Prehistoric periods (Maslyk et al. 1997:30). The presence of these artifacts, on the surface suggested that the area is severely deflated and the potential for isolable components and intact deposits was low (Maslyk et al. 1997:35). 41WB414 was subsequently investigated with three 1-x-1 m units, and three backhoe trenches. Maslyk et al. (1997) note that the units and trenches were in areas that were less likely to contain intact deposits. $41 \mathrm{WB} 414$ was recommended as not eligible for listing in the NRHP or for designation as a SAL, although noted in the report was the proviso that only a limited and narrow corridor was subject to testing (Maslyk et al. 1997:35). 



\section{Chapter 3: Field and Laboratory Methods}

The aerial photograph and topographic map suggested two different landforms were bisected by Chacon Creek. For testing purposes, the APE north of Chacon Creek, essentially land immediate to and within the floodplains of the creek, is referenced as "the northern section." The APE south of Chacon Creek, is a Terrace $1\left(\mathrm{~T}_{1}\right)$ or an "uplands" of the creek and for purposes of identification is referred to as "the southern portion."

\section{Pedestrian Survey and Shovel Testing}

For surveys of this size, the THC requires at least one shovel test for every two acres. Given that there were two known archaeological sites adjacent to and abutting the project area, CAR excavated sixty shovel tests (or approximately 4.2 shovel tests for every acre). Prior to field work, shovel test locations were laid out in a $30 \mathrm{~m}$ grid pattern over an aerial photo of the project area to maximize the coverage of the project area. This geo-referenced image was then downloaded into Trimble GeoXT GPS units and used by the crew to locate shovel tests. Shovel tests were $30 \mathrm{~cm}$ in diameter and excavated to a maximum depth of $60 \mathrm{~cm}$. Excavation levels did not exceed $10 \mathrm{~cm}$ in thickness, and observations on each level were made on standardized archaeological shovel test forms. All sediments were screened through $1 / 4$ inch mesh, and all artifacts were collected, processed, and analyzed at the CAR laboratory. No surface collections were to be made unless an artifact was temporally diagnostic.

\section{Site Recording and Identification}

Although no new archaeological sites were documented during investigations, the following criteria were used to define a site: 1) locations with at least five artifacts within a $30 \mathrm{~m}^{2}$ area or; 2) a location containing a single cultural feature such as a hearth, either on surface or exposed in a shovel test or; 3) a location with a positive shovel test containing at least three artifacts within a given 10-cm level or; 4) a location with a positive shovel test containing at least five total artifacts or; 5) two positive shovel tests located within $30 \mathrm{~m}$ of each other.

\section{Revisiting and Testing of Sites}

Based on consultation with Skipper Scott of the U.S. Army Corps of Engineers and City officials (Stephen Geiss), additional shovel tests, if warranted, could be placed within the boundaries of 41WB413 and 41WB414 that extended into the project area. Additionally, if shovel testing determined that intact deposits remained, $1-\mathrm{x}-1 \mathrm{~m}$ units would be placed in either or both of the two sites. The positioning of test units would be conditioned by the presence of intact deposits and/or features encountered during shovel testing or the possibility of encountering intact deposits and/or features. Three 1-x-1 test units were excavated with their locations recorded with a GPS. Test unit were excavated in arbitrary $10 \mathrm{~cm}$ levels with all matrix screened through a $1 / 4$ inch wire mesh screen. The test units were terminated when two consecutive levels were sterile for cultural materials. Documentation of the test units consisted of completion of level forms documenting cultural materials and soil for each level. Photographs and/or a scaled drawing of one representative wall profile were completed for each unit. Soil samples were collected from each level of the test units for soil identification and analysis. In addition, charcoal and charcoal-stained soils were collected for possible further analysis.

\section{Laboratory Methods}

All cultural material collected during the survey was prepared in accordance with federal regulation 36 CFR part 79, and in accordance with current guidelines of the Center for Archaeological Research. Artifacts were processed in the CAR laboratory where they were washed, air-dried, and stored in archival-quality bags. Artifacts were sorted into appropriate analytical categories. Acid-free labels were placed in all artifact bags. Each label displays provenience information and a corresponding lot number laser printed or written in pencil. Artifacts were separated by class and stored in acid-free boxes identified with standard labels. The data was entered into a Microsoft Access database. All artifacts are permanently curated at CAR. Field notes, forms, and hard copies of photographs were placed in labeled archival folders. All field forms were completed in pencil. Documents and forms were printed on acid-free paper and any soiled forms were placed in archival-quality page protectors. A copy of the final report in Adobe Acrobat ${ }^{\circledR}$ file format and all digital material pertaining to the project, including photographs, were burned onto a $\mathrm{CD}$ and permanently curated with the field notes and documents at the Center for Archaeological Research. 



\section{Chapter 4: Survey Results}

The survey and eligibility testing of the Killam Lake Wetlands Area project was completed between February 19 and February 25, 2008. This chapter discusses the results of that investigation. The fieldwork consisted of an intensive pedestrian survey accompanied by shovel testing of the project area. Archaeological investigations also included a revisit of 41WB413 and eligibility testing of 41WB414.

\section{Shovel Tests}

Sixty shovel tests were excavated within the APE (Figure 4-1). Of the sixty shovel tests, five shovel tests were positive for cultural materials. Appendix A lists the depths and artifacts recovered from all shovel tests. Using the delineation of "northern portion" and "southern portion" introduced in the methods chapter, this section divides the discussion of the results of testing based on this nomenclature.

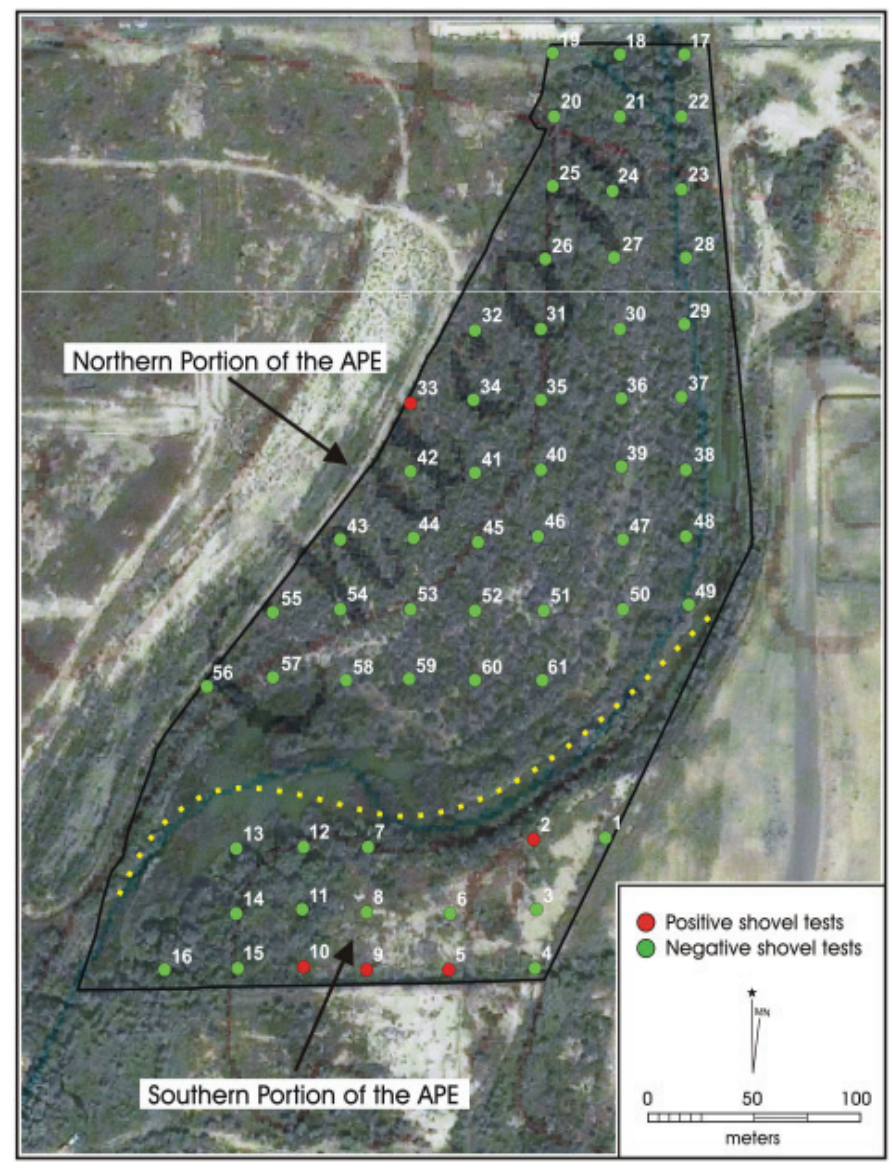

Figure 4-1. Map showing distribution and results of shovel testing.

\section{Northern Portion of the APE}

The northern portion of the project area consisted of approximately $12,700 \mathrm{~m}^{2}$ of $\mathrm{T}_{1}$ formations with the majority of the remaining acreage, $34,000 \mathrm{~m}^{2}$, located in the floodplain of Chacon Creek. The soils from $\mathrm{T}_{1}$ of the northern area consisted of approximately ten to twenty $\mathrm{cm}$ of compact, medium brown, silty sand overlying a soft, yellowish brown (10YR 5/4), compact, silty sand. The soils within the floodplain consisted of moist to wet, soft grayish brown (10YR 5/2) silty clay overlaying a wet, soft pale brown silty, very fine sand. Vegetation in this northern portion consisted of dense, tall grasses and mesquite which made surface visibility poor. Of the 45 shovel tests excavated in this portion of the project area, only ST33 was positive for cultural materials consisting of two pieces of burned sandstone.

\section{Southern Portion of the APE}

The southern portion of the APE consisted of approximately $12,500 \mathrm{~m}^{2}$ of $\mathrm{T}_{1}$ and $6,200 \mathrm{~m}^{2}$ of the floodplain of Chacon Creek. The southern boundary of the APE was delineated by a drainage, and previous pipeline easement. The soils found in the floodplain consisted of moist to wet silty sands, followed by soft grayish brown (10YR 5/2) silty clay overlaying a wet, soft pale brown silty, very fine, sand. Terrace 1 consisted of a deflated landform eroding from the northeast to the south-southwest corner. Sixteen shovel tests were excavated in this portion of the project area with four of the shovel tests positive for cultural materials (Figure 4-1). Cultural materials found in the shovel tests included debitage and burned rock. ST10 initially contained a charcoal- stained soil in Level 5 (40-50 cmbs). In addition, three pieces of debitage were found in this level. Visibility in the majority of the southern portion was poor (Figure 4-2). However, in areas free of vegetation, surface visibility increased to $90 \%$ and revealed non-diagnostic tools (uniface, cores and bifaces), debitage and burned rock. One isolated find, a late prehistoric projectile point preform, possibly a "Mission" (Guerrero type) or Fresno type (Turner and Hester 1993) was recovered during site reconnaissance. Given the site definition outlined in the methods section, CAR recommends the extension of the present boundary of $41 \mathrm{WB} 414$ to include the positive shovel tests and the location of this diagnostic.

In addition, to the pedestrian survey of the APE, Skipper Scott of the U.S. Corps of Engineers, requested reexamination of the eligibility status of 41WB413 and 41WB414. If warranted, 


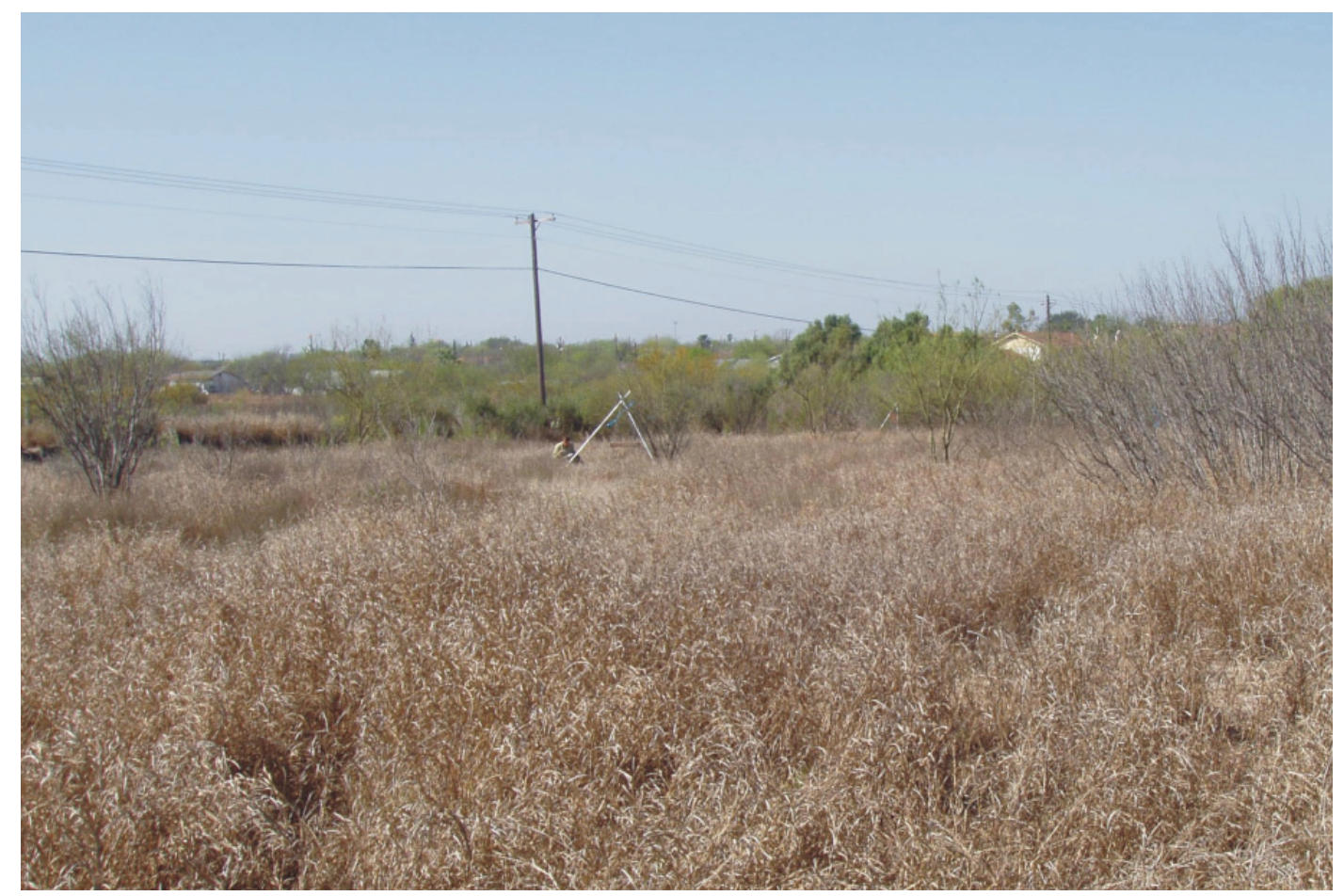

Figure 4-2. Photograph of "southern portion" of project area showing dense grass cover.

additional shovel tests, as well as $1-\mathrm{x}-1 \mathrm{~m}$ test units could be placed within their respective boundaries. $41 \mathrm{WB} 413$ was reexamined and no archaeological artifacts or features were found on the surface or revealed in the eroded drainages. No additional shovel tests or test units were placed within the boundary of 41WB413 (Figure 4-3). Furthermore, CAR concurs with the previous assessment (Maslyk et al. (1997) that $41 \mathrm{WB} 413$ is not eligible for nomination to the NRHP.

\section{Eligibility Testing of $41 \mathrm{WB} 414$}

Three test units were placed adjacent and within site 41WB414 (Figure 4-4). The placement of the three units was based on the results of shovel testing, as well as surface artifact concentrations. Test Unit 1 (TU1) was located in the western most portion of the site at its lowest elevation and immediately north of ST10. The location of Test Unit 2 (TU2) was based on the relatively high concentration of visible surface artifacts. Test Unit 3

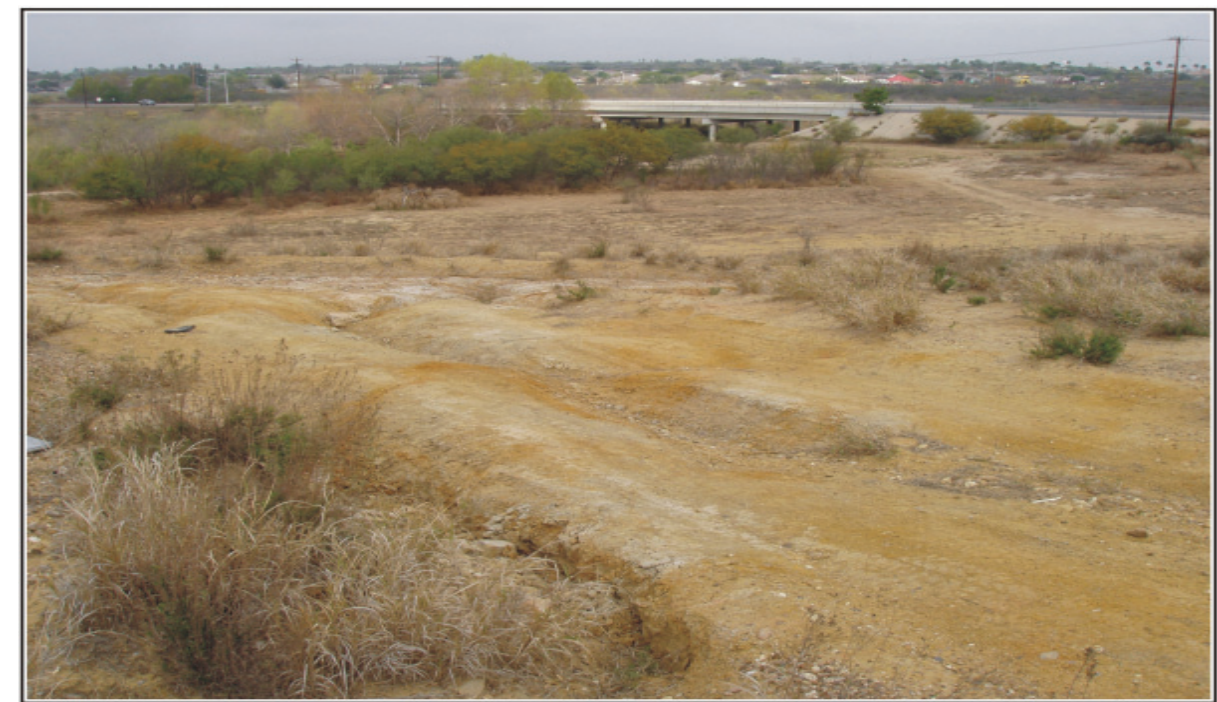

Figure 4-3. Photograph of 41 WB413 showing damage to site from erosion. (TU3) was placed within the original boundary of $41 \mathrm{WB} 414$. It is the furthest east of the three units and its location is at the highest elevation of the project area. This section describes the eligibility testing of 41WB414. Appendix A lists the provenience of all artifacts recovered during this phase of testing.

Test Unit 1 was excavated in seven levels to a depth of $70 \mathrm{cmbd}$. TU1 was excavated to examine the charcoal stain found in ST10. Figure 4-5 shows the profiles of all test units after excavation with a graph of the amount of debitage per level over laid on the profile. Based upon the 
This page has been

redacted because it

contains restricted

information. 


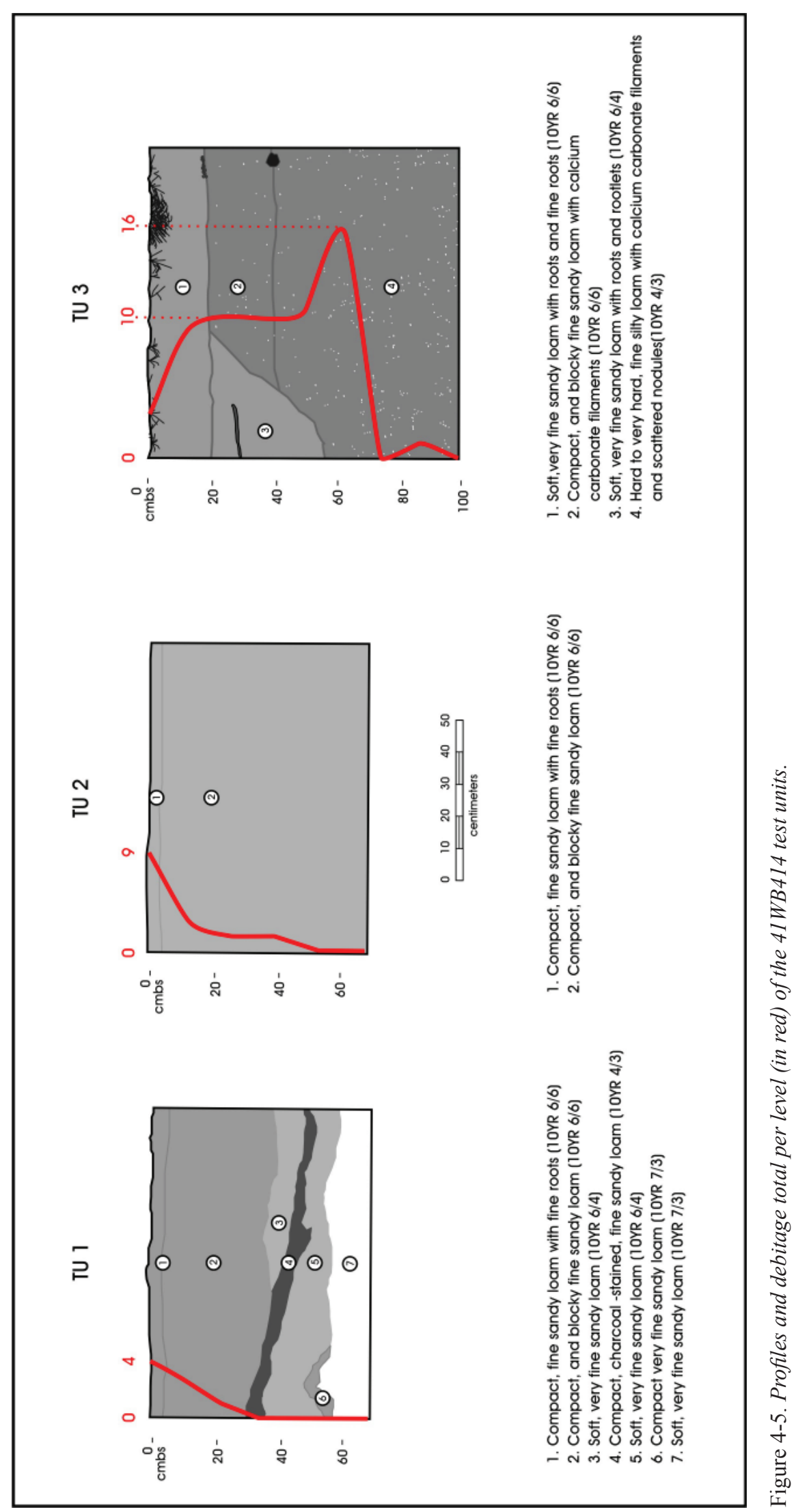


corner of the unit there was a krotovina at approximately 40 cmbd. Gravels increased from approximately $5 \%$ in Levels 1 through 3 to $30 \%$ in Level 4 . The amount of gravel decreased to $5-10 \%$ in Level 5 to $<1 \%$ in the remaining levels.

Cultural materials in TU3 consisted of a lithic tool, debitage, burned bone, and burned sandstone. Modern artifacts found included glass and a bullet and were limited to the upper 30 cmbd. A total of fifty-nine pieces of debitage were recovered with $78 \%(n=46)$ of the debitage found in Levels 4 thru 7 . The total quantity and density of debitage per level found in TU3 is substantially higher than found in the other two units. Isolated burned sandstone and fire-cracked rock were found throughout all levels. Burned bone fragments were found in Levels 4 and 6. In Level 5 (40-50 cmbd), a uniface, as well as two large burned rocks (one each of chert and sandstone), were recorded. Given the high frequency of artifacts, Levels 3 through 6 may represent the remnants of an intact buried surface suggesting that the higher elevations of the southern APE may contain intact deposits. Although TU3 exhibited less erosion than the remainder of the site, due to their sparseness and low research value, the deposits are not eligible for nomination to the NRHP. Further work is not recommended at the site.

\section{Summary}

The archaeological investigations of the Killam Lake Wetlands Area project included an intensive pedestrian survey accompanied by shovel testing and test units. For purposes of investigation and discussion, the APE was divided into a northern and southern section bisected by Chacon Creek. Sixty shovel tests were excavated and of the shovel tests a total of five were positive for cultural materials. One shovel test in the northern portion was positive. The recovered artifacts consisted of a small quantity of burned sandstone. Based upon the lack of any other cultural materials, the northern portion of the APE did not merit further investigation. The revisit of $41 \mathrm{WB} 413$ concluded that no additional work is recommended at the site. CAR recommends the boundary of $41 \mathrm{WB} 414$ be extended to the west to incorporate the positive shovel tests, test units and surface finds. The northern portion of 41WB414 appeared to be less impacted by erosion but based on the low density of materials and their minimal research potential, further work at the site is not recommended and the site does not warrant NRHP listing or formal designation as an SAL. 



\section{Chapter 5: Summary and Recommendations}

The Center for Archaeological Research of the University of Texas at San Antonio conducted an archaeological survey of the Killam Lake Wetlands Area project located in Webb County, Texas for the City of Laredo Solid Waste Services Department in February of 2008. The project area is within the Chacon Creek watershed immediately east of the City of Laredo. The archaeological work was conducted to determine whether buried cultural deposits exist in the APE and whether any hitherto undocumented sites would be impacted by the undertaking. The archaeological survey and testing within the APE was completed in accordance with the mandates of the Antiquities Code of Texas, and adhered to the requirements of Section 106 of the NHPA.

CAR excavated sixty shovel tests within the Killam Lake Wetlands APE. No new sites were documented during the pedestrian survey. Site $41 \mathrm{WB} 413$ has been severely impacted by natural erosion and a pipeline installation, therefore, further work is not recommended at the site. Furthermore, CAR recommends that the site is not eligible for listing to the NRHP. Based upon the presence of cultural material found in shovel tests abutting $41 \mathrm{WB} 414$, CAR proposes extending the boundary of 41WB414 to include these shovel tests, test units, as well as the temporal diagnostic found on the surface. Three $1-\mathrm{x}-1 \mathrm{~m}$ test units were placed in and adjoining 41WB414. No evidence of temporal diagnostics or cultural features were found in the excavations. Based on the findings from these investigations, CAR recommends that $41 \mathrm{WB} 414$ is not eligible for inclusion to the NRHP or formal designation as an SAL. Therefore, CAR recommends that the remediation of the Killam Lake Wetlands proceed as proposed. 



\section{References Cited}

Blair, W.F.

1950 The Biotic Provinces of Texas. Texas Journal of Science 2(1):93-117.

Clark, J.W., Jr.

1992 Archaeological Tests on Two Prehistoric Sites on Spur 400, Webb County, Texas. Texas Department of Transportation, Division of Highway Design, Austin.

Collins, M.B.

1995 Forty Years of Archeology in Central Texas. Bulletin of the Texas Archaeological Society 66:361-400.

Hall, G.D., T.R. Hester, and S.L. Black

1986 The Prehistoric Sites at Choke Canyon Reservoir, Southern Texas: Results of the Phase II Archaeological Investigations. Choke Canyon Series. Vol. 10. Center for Archaeological Research, The University of Texas at San Antonio.

Hester, T.R.

1995 The Prehistory of South Texas. Bulletin of the Texas Archeological Society 66:427-459.

Kibler, K.W.

1996 Results of the Initial Archaeological; Survey for the Chacon Creek Sewer Interceptor, Webb County, Texas. Hicks and Company, Letter Report No.412, Austin.

Maslyk, P., K.W. Kibler and R.C. Fields

1997 Archeological Site Testing and Additional Archeological Survey for the Chacon Creek Sewer Interceptor. Technical Reports, Number 24. Prewitt and Associates, Austin.

Quigg, J.M., C. Lintz, G. Smith, and S. Wilcox.

2000 The Lino Site: A Stratified Late Archaic Campsite in a Terrace of the San Idelfonzo Creek, Webb County, Texas. TRC Mariah Associates Inc., Technical Report, No 23756 and Archeological Studies Program, Report No. 20 Texas Department of Transportation, Environmental Affairs Division, Austin.

Quigg, J.M., S. Pritchard, and G. Smith.

2002 The Boiler Site: Utilization of an Upland Setting Over the Last 4200 Years, Webb County, Texas. TRC Mariah Associates Inc., Technical Report, No. 27277 and Archeological Studies Program, Report No. 45, Texas Department of Transportation, Environmental Affairs Division, Austin.

Sanders, R.R. and W.J. Gabriel

1985 Soil Survey of Webb County, Texas. Soil. United States Department of Agriculture. Soil Conservation Service. Washington, D.C.

Texas Historical Commission (THC)

2007 Texas Archeological Sites Atlas, http://www.nueces.thc.state.tx.us/, accessed Jan 2008. 
Tomka, S.A., T.K. Perttula, and R.J. Hard

1997 Archaeology of the Rio Grande and Central Coastal Plains, Texas: A Planning Document. Archaeological Survey Report, No. 266. Center for Archaeological Research, The University of Texas at San Antonio.

Turner, E.S. and T.R. Hester

1993 A Field Guide to Stone Artifacts of Texas Indians. Second edition. Gulf Publishing, Houston. 


\section{Appendix A}

\section{Results of Shovel Test and Test Unit Excavations}



Table A-1. Shovel Test Results

\begin{tabular}{|c|c|c|}
\hline ST \# & Final Depth (cm) & Artifacts \\
\hline 1 & 36 & none \\
\hline 2 & 60 & ochre \\
\hline 3 & 60 & burned rock \\
\hline 4 & 60 & none \\
\hline 5 & 60 & debitate (1), burned rock \\
\hline 6 & 60 & none \\
\hline 7 & 60 & none \\
\hline 8 & 60 & burned rock \\
\hline 9 & 60 & debitate (2) \\
\hline 10 & 60 & debitage (1), charcoal \\
\hline 11 & 60 & none \\
\hline 12 & 60 & none \\
\hline 13 & 60 & none \\
\hline 14 & 60 & none \\
\hline 15 & 60 & none \\
\hline 16 & 60 & none \\
\hline 17 & 60 & none \\
\hline 18 & 60 & none \\
\hline 19 & 40 & none \\
\hline 20 & 60 & none \\
\hline 21 & 60 & none \\
\hline 22 & 60 & none \\
\hline 23 & 60 & none \\
\hline 24 & 60 & none \\
\hline 25 & 60 & none \\
\hline 26 & 60 & none \\
\hline 27 & 60 & none \\
\hline 28 & 60 & none \\
\hline 29 & 60 & none \\
\hline 30 & 60 & none \\
\hline 31 & 60 & none \\
\hline
\end{tabular}

\begin{tabular}{|c|c|c|}
\hline ST \# & Final Depth (cm) & Artifacts \\
\hline 32 & 60 & none \\
\hline 33 & 60 & burned rock \\
\hline 34 & 60 & none \\
\hline 35 & 60 & none \\
\hline 36 & 60 & none \\
\hline 37 & 60 & none \\
\hline 38 & 60 & none \\
\hline 39 & 60 & none \\
\hline 40 & 60 & none \\
\hline 41 & 60 & none \\
\hline 42 & 60 & none \\
\hline 43 & 60 & none \\
\hline 44 & 60 & none \\
\hline 45 & 60 & none \\
\hline 46 & 60 & none \\
\hline 47 & 60 & none \\
\hline 48 & 50 & none \\
\hline 49 & 60 & none \\
\hline 50 & 60 & none \\
\hline 51 & 60 & none \\
\hline 52 & 60 & none \\
\hline 53 & 60 & none \\
\hline 54 & 60 & none \\
\hline 55 & 60 & none \\
\hline 56 & 60 & none \\
\hline 57 & 60 & none \\
\hline 58 & not excavated & none \\
\hline 59 & 60 & none \\
\hline 60 & 37 & none \\
\hline 61 & 60 & none \\
\hline
\end{tabular}




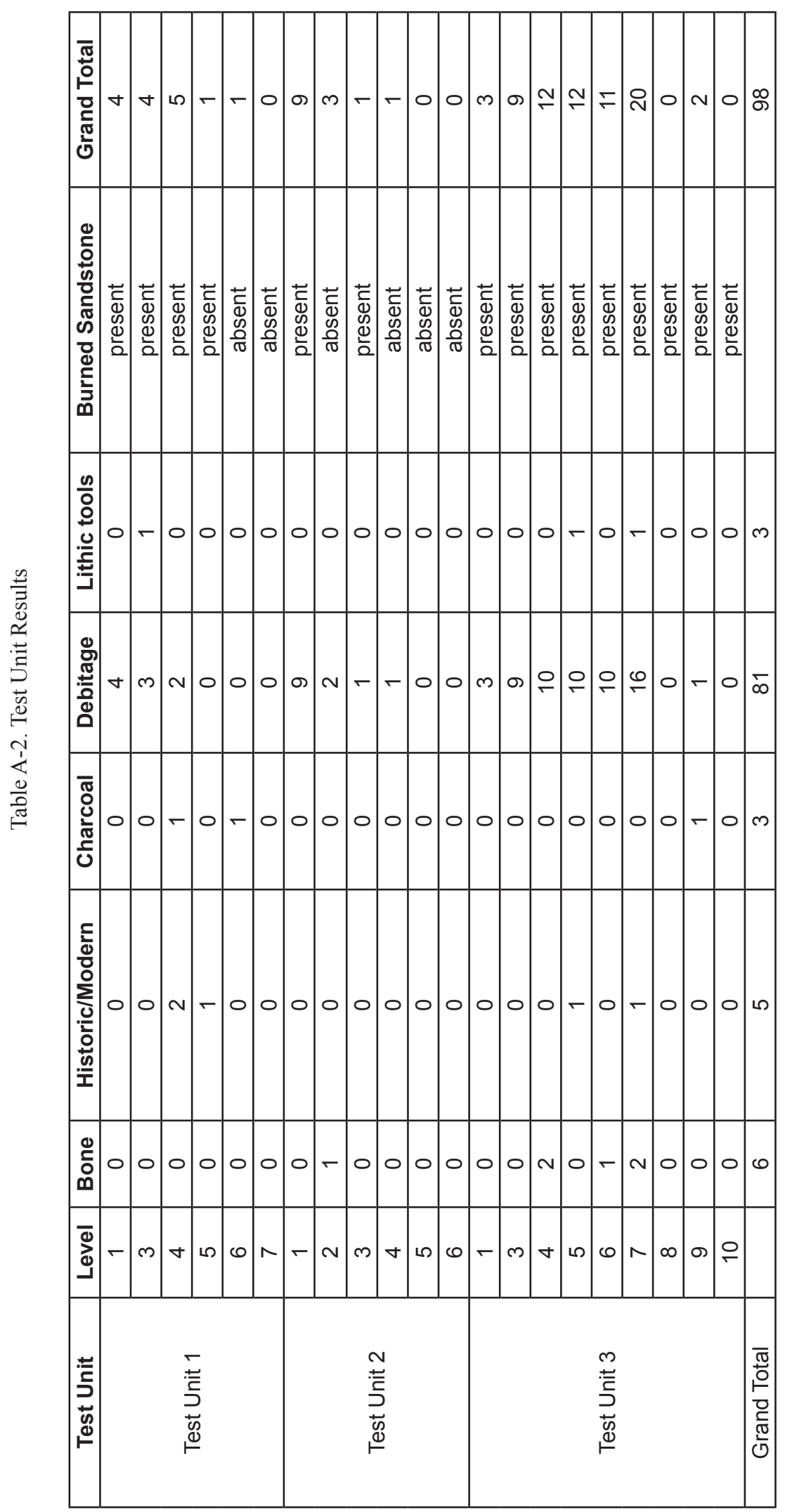

